УДК 378

DOI 10.11603/m.2414-5998.2021.4.12701

\author{
I. I. Vorona \\ ORCID https://orcid.org/0000-0002-9118-9456 \\ ResearcherID Q-4691-2016 \\ O. D. Kolodnytska \\ ORCID https://orcid.org/0000-0002-7102-3870 \\ ResearcherID Q-5936-2016
}

\author{
I. Horbachevsky Ternopil National Medical University
}

\title{
CRITERIA AND LEVELS OF FORMATION OF PROFESSIONAL COMMUNICATIVE CULTURE
}

\author{
I. I. Ворона, О. Д. Колодницька \\ Тернопільський національний медичний університет імені І. Я. Горбачевського МОЗ Украӥни \\ КРИТЕРІЇ ТА РІВНІ СФОРМОВАНОСТІ ПРОФЕСІЙНО-
КОМУНІКАТИВНОЇ КУЛЬТУРИ
}

Abstract. The article is devoted to the issue of diagnosing the level of formation of the professional communicative culture of future physicians. The description of the criteria, indicators, and levels of formation of the professional communicative culture of future physicians determined in the course of the study, is presented on the basis of the integration of pedagogical, psychological, and linguistic studies. A brief substantiation and characteristics of certain criteria (motivational, cognitive, personal value, and practical performance) and their indicators are given. The levels of formation of the professional communicative culture of future physicians were defined: high, medium, low.

The formation of the motivational criterion is the starting point for the existence of the professional communicative culture of the future specialist since this phenomenon cannot arise outside the student motivation. Motivation for choosing a profession determines the choice of professional ideals, the formation of professional plans, self-analysis, self-esteem, and the personal exactingness towards himself/herself. It acts as the leading motive of education, stimulating the cognitive activity of students.

The cognitive criterion reflects the level of mastering the knowledge necessary for successful professional communication, which forms the theoretical basis of communication, serves as the basis for the development of practical communication skills.

The personal value criterion was determined on the basis of the formation of values that determine the value attitude of the person to the chosen profession, the presence of universal values and values of professional self-realization, testify to the understanding of the readiness to identify personal initiative and further professional growth.

The practical performance criterion determines the communicative culture of the future specialist. The level of professional skills is not only the practical embodiment of theoretical general cultural and professional knowledge but also their productive application in cognitive activity and the implementation of interpersonal and professional interaction at a high level of professional culture.

Key words: professional communicative culture; formation of professional communicative culture; criteria; indicators; levels of formation; future physicians.

Анотація. Статтю присвячено проблемі діагностики рівня сформованості професійно-комунікативної культури майбутніх медиків. На основі інтеграції досліджень з педагогіки, психології та лінгвістики подано опис визначених у ході дослідження критеріїв, показників та рівнів сформованості професійно-комунікативної культури майбутніх медиків. Подано стисле обгрунтування й характеристику визначених критеріїв (мотиваційного, когнітивного, особистісно-ціннісного та практичнодіяльнісного) та їх показників. Виокремлено рівні сформованості професійно-комунікативної культури майбутніх працівників медичної сфери: високий, середній, низький.

Сформованість мотиваційного критерію є відправною точкою існування професійно-комунікативної культури майбутнього фахівця, оскільки цей феномен не може виникнути поза мотиваційною сферою студентів. Мотивація в обранні фаху зумовлює вибір професійних ідеалів, формування професійних планів, самоаналіз, самооцінку й вимогливість особистості до себе, виступає провідним мотивом освіти, який стимулює пізнавальну діяльність студентів.

Когнітивний критерій відображає рівень засвоєння знань, необхідних для успішної професійної комунікації, котрі формують теоретичну основу комунікації, служать підгрунтям для розвитку практичних комунікативних умінь.

Особистісно-ціннісний критерій визначено на основі сформованості ціннісних орієнтирів, які визначають ціннісне відношення особистості до обраної професії, наявність загальнолюдських цінностей і цінностей професійної самореалізації, свідчать про розуміння готовності до виявлення особистої ініціативи й подальшого професійного зростання.

Практично-діяльнісний критерій визначає комунікативну культуру майбутнього фахівця. Рівень професійних умінь $є$ не тільки практичним втіленням теоретичних загальнокультурних та професійних знань, але й продуктивним їх застосуванням у пізнавальній діяльності та здійсненні міжособистісної та професійної взаємодії на високому рівні професійної культури.

Ключові слова: професійно-комунікативна культура; сформованість професійно-комунікативної культури; критерії; показники; рівні сформованості; майбутні медики.

(C) I. I. Vorona, O. D. Kolodnytska 
Introduction. Ukraine's desire to move closer to world standards in the field of health care requires, first of all, high-quality training of physicians whose qualifications would correspond to the international and European levels. The necessary qualities of a medical specialist are high culture, the deepest moral convictions, the ability to act according to the laws of humanism and spirituality. The set tasks largely determined the importance of forming a professional communicative culture of medical students, without which conscious participation in professional life is impossible.

Professional communicative culture is an integral part of the professionalism of every specialist. It plays the main role in the general cultural and personal professional development. Therefore, the training of a highly professional, communicatively competent physician of the new generation is an urgent social need, the satisfaction of which requires higher medical education to focus on improving the level of professional communicative culture of future physicians.

The issue of the formation of communication culture as an important factor in the professionalism of a specialist has become the object of V. Andreev, Yu. Zhukov, I. Zaretska, F. Kuzin, N. Panin, G. Sahach, G. Shchokin, E. Yashchenko, and other scientific researchers. L. Bourdain, S. Herasimenko, N. Zamkova, G. Medvid (G. Petruk), H. Miasoid, O. Uvarkina, V. Cherevko studied the criteria, indicators and levels of professional activity of representatives of different professions. However, the existing experience needs to be interpreted from the standpoint of identifying opportunities to improve the effectiveness of pedagogical diagnosis of the criteria and indicators of professional communicative culture. The issue of determining scientifically grounded criteria for evaluating the level of formation of the culture of professional communication among future physicians is of particular relevance.

The aim - to substantiate the criteria and levels of formation of professional communicative culture of future physicians while receiving medical education.

Methods. The following general scientific methods and techniques are used in the study: analysis, synthesis, abstraction, comparison, a descriptive method with methods of observation, comparison and generalization.

Results. The professional communicative culture of the future medical specialist is an integral dynamic personal structure, which includes a system of universal and professional values, ethical knowledge, communication skills and qualities, samples of speech behaviour, norms and rules of communication activities designed by a person in professional activity in accordance with the aims and objectives and ensure its high efficiency [14].

We took into account different interpretations of this concept while developing a system of criteria for the studied phenomenon. A criterion in encyclopaedic dictionaries is defined as "a principle for determining, evaluating an object, phenomenon; the attribute taken as the basis for the classification" [2, p. 305], "basis for evaluating, defining or classifying something" [7, p. 588]. In pedagogical theory, this term is understood as an objective essential quality, through which a comparative evaluation of a certain phenomenon is carried out, the degree of its qualitative and quantitative changes is revealed [6, p. 149]. V. Zagvyazinskiy determines the criterion as a generalized indicator of the development of the system, the success of the activity, the basis for the classification [4, p. 199].

Thanks to definitions of the formation of professional communication culture in various fields in reference literature, pedagogical theory, personal researchers, it is established that the criteria are understood as features on the basis of which the classification of changes in the formation of professional pedagogical culture. Therefore, taking into consideration the above, we consider the criterion of the formation of professional communicative culture as a sign or property that allows us to evaluate the state and level of development of this type of culture in future physicians. Each criterion has its own system of indicators characterizing a certain aspect [8]. Hence, indicators are data that indicate the development and course of the criteria for expressing the culture of professional communication.

Analysis of modern psychological and pedagogical researches has revealed different approaches to the problem of determining the criteria and indicators of the formation of the communicative culture of future specialists. Criteria for diagnosing the development of communicative culture of social inspectors were determined in the work of H. Miasoid. They include: information and cognitive criterion, indicators of which include professional and moral skills and awareness of one's own level of communicative culture; motivational value criterion, characterized by values and motivation; operational performance criterion, the indicators of which are determined by procedural communicative, interactive, perceptual skills [11, p. 9-10].

The system of criteria of the formation of the professional communication culture of communications engineers, proposed by scientist $\mathrm{H}$. Medved (H. Pet- 
ruk), involves motivational, semantic operational, and personal criteria. The indicators of the motivational criterion were determined by the external and internal motivation of the future specialist to master this type of culture, the indicators of the semantic operational criterion were the assimilation of communicative knowledge and the development of communicative skills, and the indicators of the personal criterion were the communicative qualities that are essential for professional communication [13].

S. Herasimenko distinguishes the criteria of communicative culture of future medical workers according to its structural components. The scientist considers the knowledge of their emotions, emotion management, empathy, understanding of nonverbal language, attraction as the criteria of the emotional component. Criteria of the cognitive component include a system of values, beliefs and attitudes, communicative and linguistic knowledge and skills, creative thinking, reflection, self-control. Interaction planning and interaction strategies, structured interaction, communicative orientation are defined as criteria of the behavioural component [3, p. 205-206].

In our opinion, the formation of the professional communicative culture of the future specialist involves primarily the formation of its structural components. So, we consider it appropriate while choosing criteria based on the substantive structure of professional communicative culture. We consider the professional communicative culture of future physicians as a complex dynamic personal education, including a system of universal and professional values, speech and ethical knowledge, communication skills and qualities, norms and rules of professional communication, which are related to the specifics of the profession and ensure high efficiency of professional communication. In its structure, we define four interrelated components: motivational (motivation to master the professional communicative culture), cognitive (knowledge necessary for successful professional communication), personal value (communicatively significant personal qualities and a system of values that promote mutual understanding and successful performance communicative tasks), practical performance (communicative skills that ensure the implementation of professional communication). We define criteria for the formation of the professional communication culture of future physicians identical to its structural components, respectively.

Motivational criterion is determined on the basis of a professional-motivational approach to the innovative development of higher education. Therefore, we understand the motivational criterion as the manifestation of the need to master professional communicative competence, which is determined by the personal professional orientation and the structure of its values, which are its indicators. The indicators of this criterion include those motives that have the most significant impact on the formation of educational motivation, guide the personal cognitive activity to master the profession, develop their potential and contribute to success in educational and professional activities. These motives include an internal need to master a professional communicative culture, dominant personal values, and the professional orientation of a person.

The internal need for mastering a professional and communicative culture is a driving force for mastering theoretical and practical knowledge, and on their basis - the ability to demonstrate a professional communicative culture. This driving force is the desire to improve professionally. Professional selfimprovement is an internal process of high-quality self-changes, providing an awareness of the need for self-improvement, deep self-analysis, and one's own reflections; motivated, purposeful and organized selfmovement towards the best in oneself.

Such indicator of the motivational criterion as the dominant values of the personality appears to be an adequate indicator of the developed personality. Personality possesses values as its own qualities. Personal growth depends on the extent to which such a personality is combined with a generally accepted system of spiritual values. This is manifested in personal activities and creativity in accordance with the value orientations of humanism. It is important what value orientations make up the living, personal and professional space of the future physician because they will determine and fill the content of the activities, he/she will carry out.

We consider the professional orientation in the plane of personal self-actualization in the field of professional activity. The source that ensures the creative activity of future physicians is the motives of personal selfactualization. The mechanism for the emergence of such motives is the system of future specialist personal professional value orientations, in which the dominant role belongs to the humanistic orientation of the activity and his social responsibility.

Cognitive criterion is determined on the basis of the cognitive approach in psychology. Within it, a person is considered as one who "understands, analyses", because he/she is in the world of information that must 
be understood, evaluated, used. Thus, this criterion provides a significant component, the indicators of which are the understanding of the essence and importance of professional and communicative culture, awareness of the impact of personal qualities on the effectiveness of communication, mastery of language norms in the professional sphere.

One of the indicators of the cognitive criterion is understanding the essence and meaning of professional and communicative culture. The manifestation of professional communicative culture depends on the awareness of its essence and significance. Intuitive knowledge can be used, but understanding the definition of professional communication culture and its importance in the educational process, the future specialist will choose appropriate ways of its manifestation (compliance with language norms, logical construction of the message, feedback, communication conditions, and features of the conversational counterpart, application of rhetorical and communicative qualities, etc.).

An important indicator of the cognitive criterion is the awareness of the influence of personal qualities on the effective communication. While organizing and implementing professional communication, it is important to take into consideration personal qualities, because this process always pursues a specific goal. Efficiency is not a desired, but a necessary result. Consequently, the following personal qualities affect the effectiveness of communication: introversion - extroversion, empathy, dominance, conflict and aggressiveness, tolerance, shyness, timidity (social cowardice), rigidity - mobility.

Mastering the linguistic norms in the professional sphere is an important indicator of speech culture. We define two groups of knowledge, without which it is impossible to carry out professional communication linguistic competence and communicative knowledge. According to the interpretation, the concept of "competence", reflected in the explanatory dictionaries, means: good knowledge of something; a range of issues in which a certain person has knowledge, experience [2, p. 560], we define linguistic competence as knowledge of the language code, that is, the rules by which correct speech structures and messages are formed and transformed. Scientists identify communicative knowledge as knowledge about the essence of communication, its types and styles, about means of communication, communicative techniques and technologies, their effectiveness in different situations with different people, etc. [5, p. 9].
Personal value criterion assesses the formation of communicatively significant personal qualities of the future physician and the system of value orientations. Among the qualities that contribute to the effectiveness of professional communication, the most important for the formation of professional communication culture of future physicians, we define goodwill, empathy, communicability, reflexivity, balance. In psychology and pedagogy, value orientations are defined as a selective, socially determined, stable system of personal interests and needs which determines the relationship of the person to a set of material and spiritual values and ideals [6, p. 382]. We identify the system of basic humanistic values (life, kindness, agape, compassion, justice, conscience, respect for human dignity) proposed in the V. Kuznetsova study to the values that play a leading role in the formation of the professional communicative culture of future physicians [9, p. 8] and the K. Kurenkova system of professional values of nurses (mercy, love for people, benevolence, strictness, collegiality, professional reputation, love for the medical profession, professional dignity) [10, p. 7-8].

The first indicator of the personal value criterion is communicative tolerance. Each participant in the communication process demonstrates behavioural signs of communicative tolerance or lack of it. They depend on personal qualities and have a significant impact on both the process and the result of communication. These signs include: acceptance or understanding of a person's individuality, using oneself as a standard in assessing others, categorical or conservatism in assessing people, the ability to hide and smooth out unpleasant feelings when faced with the uncommunicative qualities of a conversational counterpart, tolerance for physical or psychological discomfort during communication.

Communication self-control is an important indicator of personal value criteria. Constant control over your behaviour, speech, expression of emotions will ensure entering any role easily, flexibility of reaction to changing situations. Therefore, high communicative control can be one of the indicators of the formation of professional communicative culture of the specialist.

The next indicator of the personal value criterion is the manifestation of empathy in professional communication. One of the characteristics of physician's activity is the need for emotional support of the patient or his relatives. Showing kindness, compassion the physician empathizes while evaluating. One of the important manifestations of a specialist's empathy is the ability to understand the emotional state of the conversational counterpart by external signs, to be able 
to listen and hear, to show compassion appropriately. Usually, the personal psychological state is manifested in human speech. It is significant how a person strikes up a conversation and how he/she ends it; character is traced in the rate of speech; the content of speech conveys the spiritual world, the personal interests, and his/her focus. All this should be taken into consideration by the physician while communicating with patients.

We associate practical performance criterion with the level of mastery of basic communication skills that ensure the effective implementation of professional communication. We consider the communication style, the communication aesthetics, the ability to perceive and produce communicative means, the ability to conduct a conversation as indicators of the practical performance criterion.

Each person chooses a certain communication style. Professional communication is aimed at achieving the goal that defines this choice. This takes into consideration the personality of the conversational counterpart, the situation, conditions, needs of the conversation participants. We have used the N. Butenko types of communication: confrontational (daring), mentoring (tutoring), inspiring, informational (aimed at restoring any information) [1, p. 43].

Linguists emphasize the need for a high level of speech culture of the speaker, which consists of accuracy, brevity (conciseness), relevance, clarity, expressiveness, individuality (originality), beauty, melodiousness, lexical richness and variety, etc.

These characteristics are united by the concept of "communicative-rhetorical qualities". Supplemented with the appropriate systems of non-verbal means (acoustic, optical, tactile-kinaesthetic, temporal) and etiquette formulas of communication, they acquire aesthetics.

The analysis of the researches made it possible to identify two main groups of communicative skills, the presence of which is an indispensable condition for successful communicative interaction - the ability to perceive communicative signals and the ability to produce communicative signals. Since each profession has its own characteristics and requires special skills from a specialist, a physician should possess not only general communication skills, but also professional communication skills that allow him/her to establish contact with the conversational counterpart in the process of professional communication, to manage interaction with him/her. In our opinion, the ability to conduct a conversation is one of the main professional communicative skills of future physicians because the clinical conversation was and remains the main type of communication between physician and patient, one of the most important methods used in everyday work. In addition, the ability to conduct a conversation is a complex communicative skill, since it requires a specialist to have a set of skills: the ability of selfpresentation in communication; the ability to establish contact with the patient; the ability to understand the personality of the patient and his internal state; the ability to take into consideration the individual psychological characteristics of patients; the ability to show compassion, goodwill and respect; the ability to boost patient's self-confidence; the ability to take control of your own behaviour; the ability to overcome psychological barriers.

Thus, summarizing the above, we present the criteria and indicators of formation of the professional communicative culture of future physicians in a table 1.

Table 1. Criteria and indicators of formation of the professional communicative culture of future physicians

\begin{tabular}{|l|l|}
\hline \multicolumn{1}{|c|}{ Criteria } & \multicolumn{1}{c|}{ Indicators } \\
\hline Motivational & $\begin{array}{l}\text { - internal need to master the } \\
\text { professional communicative culture; } \\
\text { - dominant personal values; } \\
\text { - personal professional orientation }\end{array}$ \\
\hline Cognitive & $\begin{array}{l}\text { - understanding the essence and } \\
\text { meaning of professional and } \\
\text { communicative culture; } \\
\text { - the awareness of the influence of } \\
\text { personal qualities on the effective } \\
\text { communication; } \\
\text { - mastering the linguistic norms in the } \\
\text { professional sphere }\end{array}$ \\
\hline Personal & $\begin{array}{l}\text { - communicative tolerance; } \\
\text { - communication self-control; } \\
\text { - the manifestation of empathy in } \\
\text { professional communication }\end{array}$ \\
\hline Practical & $\begin{array}{l}\text { - communication style; } \\
\text { - communication aesthetics; } \\
\text { - ability to perceive and produce } \\
\text { communicative means; } \\
\text { - ability to conduct a conversation }\end{array}$ \\
\hline
\end{tabular}

Having analysed psychological and pedagogical research, based on the presented system of criteria and indicators, we have identified three levels of formation of future physicians' professional communicative culture - high, medium and low.

The high level of professional communicative culture of the future specialist is characterized by the personal humanistic orientation, the structure of value 
orientations of which is experiencing new things in the world, nature, man, help and mercy in relation to other people. A future specialist understands professional communicative culture as the personal quality, which depends on the general and communicative culture and ensures the effectiveness of professional communication, becoming a synthesis of a complex of professional competencies, values and worldview; realizes the need to ensure the effectiveness of the organization and implementation of the educational process by means of professional communication, its educational impact on the personality of the conversational counterpart; clearly defines the positive and negative impact of specific personal qualities on the effectiveness of communication; perfectly masters the norms of the Ukrainian language in the professional field; demonstrates a high level of communicative tolerance and self-control in communication, congruence (correspondence of nonverbal means to verbal ones). Is able to accurately identify emotional states and a set of nonverbal means of communication.

The high level of professional communicative culture forecasts: according to the motivational criterion - the correspondence of the leading motives for choosing a profession to its objective content, that is, the dominance of internal socially significant motives for choosing a profession; the high level of success motivation; an active realization of the need for self-improvement; according to the cognitive criterion - an excellent level of knowledge of the state and foreign languages; the high level of formation of communicative, moral, and etiquette knowledge; according to personal value criterion - the high level of development of communicative qualities; the high level of formation of humanistic and professional values; according to the practical performance criterion - the high level of formation of the skills to perceive and produce communicative signals, the ability to conduct a dialogue [12].

The medium level of formation of professional communicative culture of the future specialist is characterized by the personal idealistic orientation, the structure of value orientations of which are love, high social status, and people management, social activity to achieve positive change in society. The future specialist identifies the professional communicative culture with the speech culture in professional activities, professional, pedagogical communication, the importance of which lies in compliance with established norms and rules of communication. Awareness of the influence of personal qualities on the effectiveness of communication is based solely on understanding the semantics of nominations. Professional terminology is used in violation of the Ukrainian language. Communicative tolerance is selective, based on personal sympathy. The future specialist is honest, unrestrained in his/her emotional manifestations while communicating, his/her behaviour takes into consideration the needs of others. The medium level of formation of professional communicative culture of the future specialist is defined according to the motivational criterion - partial conformity of the leading motives for choosing a profession to its objective content, that is, the dominance of internal individually significant motives for choosing a profession; the medium level of success motivation; lack of an established system of self-improvement; according to the cognitive criterion - a good level of knowledge of the state and foreign languages; the medium level of formation of communicative, moral, and etiquette knowledge; according to personal value criterion - the medium level of development of communicative qualities; the medium level of formation of humanistic and professional values; according to the practical performance criterion - the medium level of formation of the skills to perceive and produce communicative signals, the ability to conduct a dialogue [12].

The low level of formation of professional communicative culture of the future specialist is characterized by egocentric orientation of the personality, the structure of value orientations of which is health, pleasant pastime, rest, high material well-being, searching and enjoyment of the beauty. The future specialist the professional communicative culture with the specialist professional culture, considers value in ensuring the level of perception of information by conversation participants. He/she does not aware the influence of personal qualities on the effectiveness of communication. The future specialist often uses the wrong word and phrasal stress, the form of address, not able to find synonyms for the lexemes of a professional dictionary, makes syntactic errors and reveals intolerance towards others. Communication selfcontrol is characterized by constant control over one's behaviour, speech, expression of emotions, lack of desire for flexibility of reaction to changing situations, the ability to self-revelation in communication, and straightforwardness.

The low level of formation of professional communicative culture of the future specialist is characterized by the motivational criterion - nonconformity of 
the leading motives for choosing a profession to its objective content, that is, the dominance of internal individually significant motives for choosing a profession; the low level of success motivation; suspension of self-improvement; according to the cognitive criterion - the low level of knowledge of the state and foreign languages; the low level of formation of communicative, moral, and etiquette knowledge; according to personal value criterion - the low level of development of communicative qualities; the low level of formation of humanistic and professional values; according to the practical performance criterion - the low level of formation of the skills to perceive and produce communicative signals, the ability to conduct a dialogue [12].

Depending on what value orientations prevail in a person, their content, and the correspondence between significance and realization, he/she produces a certain behavioural style, which is guided in life to achieve the goal.

Conclusions and Prospects for Research. Therefore, the conducted research allowed us to clarify the meaning of the concepts "criterion" and "indicator", to define the criteria and indicators of the formation of the professional communicative culture of future

\section{List of literature}

1. Бутенко Н. Ю. Комунікативна майстерність викладача / Н. Ю. Бутенко. - К. : КНЕУ, 2005. - 336 с.

2. Великий тлумачний словник сучасної української мови / [уклад. і гол. ред. В. Т. Бусел]. - К. ; Ірпінь : ВТФ «Перун», 2005. - 1728 с.

3. Герасименко С. Л. Формирование коммуникативной культуры будущего медицинского работника в процессе изучения иностранного языка : дисс. ... канд. пед. наук : 13.00 .08 «Теория и методика профессионального образования» / С. Л. Герасименко. - Курск, 2007. - 282 с.

4. Загвязинский В. И. Методология и методы психологопедагогического исследования : учеб. пособие для студ. высш. пед. учеб. заведений / В. И. Загвязинский, Р. Атаханов. - 2-е изд., стер. - М., 2005. - 208 с.

5. Измайлова М. А. Деловое общение : учебное пособие / М. А. Измайлова. - 2-е изд. - М. : Издательскоторговая корпорация «Дашков и К», 2009. - 252 с.

6. Коджаспирова Г. М. Педагогический словарь / Г. М. Коджаспирова, А. Ю. Коджаспиров. - М. : ИКЦ «Март»; Ростов н/Д : Издательский центр «Март», 2005. - 448 c.

7. Кононенко Б. И. Большой толковый словарь по культурологии / Б. И. Кононенко. - М. : Вече, 2003. - 511 с.

8. Кручек В. А. Критерії та показники сформованості культури педагогічної взаємодії / В. А. Кручек, О. В. Васюк // Вісник Черкаського університету. Серія «Педагогічні науки». - 2011. - Вип. 203, ч. 1. - С. 99-104. physicians, to substantiate the characteristics of each level. We used the content structure of professional communicative culture as the basis for identifying the criteria. The system of criteria for evaluating the level of development of the professional communicative culture of future physicians contains a motivational (internal need to master the professional communicative culture; dominant personal values; personal professional orientation), cognitive (understanding the essence and meaning of professional and communicative culture; the awareness of the influence of personal qualities on the effective communication; mastering the linguistic norms in the professional sphere), personal value (communicative tolerance; communication selfcontrol; the manifestation of empathy in professional communication), and practical performance (communication style; communication aesthetics; ability to perceive and produce communicative means; ability to conduct a conversation) criteria. Professional communicative culture has three levels of formation: high, medium, and low.

We consider prospects for further scientific research in the development of a model for the formation of professional communicative culture of future physicians.

9. Кузнецова В. Г. Проблеми формування гуманітарного світогляду студентської молоді / В. Г. Кузнецова // Вісник Луганського державного педуніверситету імені Тараса Шевченка. - 2001. - № 1. - С. 96-101.

10. Куренкова К. М. Про ціннісний зміст професійної культури майбутніх фахівців / К. М. Куренкова // Наукові записки кафедри педагогіки : зб. наук. праць. - Х. : Харків. нац. ун-т ім. В. Н. Каразіна, 2008. - Вип. ХХI. - С. 58-64.

11. М’ясоїд Г. I. Педагогічні умови розвитку комунікативної культури соціальних інспекторів у процесі підвищення кваліфікації : автореф. дис. ... канд. пед. наук : 13.00 .04 «Теорія та методика професійної освіти» / Г. І. М’ясоїд. - Тернопіль, 2005. - 20 с.

12. Остраус Ю. М. Критерії, показники та рівні сформованості професійно-комунікативної культури майбутніх сімейних лікарів / Ю. М. Остраус // Наукові записки Вінницького державного педагогічного університету імені Михайла Коцюбинського. Серія «Педагогіка і психологія». - Вінниця, 2016. - № 47. - С. 96-102.

13. Петрук Г. М. Критерії сформованості комунікативної культури майбутніх інженерів зв’язку / Г. М. Петрук // Витоки педагогічної майстерності : зб. наук. праць. Серія «Педагогічні науки». - Полтава, 2008. - Вип. 5. C. 228-233.

14. Vorona I. I. Professional culture in the context of future doctor training / I. I. Vorona, I. A. Prokop // Медична освіта. - 2020. - № 1. - С. 117-121. 


\section{References}

1. Butenko, N.Yu. (2005). Komunikatyvna maisternist vykladacha [Teacher's communicative skills]. Kyiv: KNEU [in Ukrainian].

2. Busel, V.T. (2005). Velykyi tlumachnyi slovnyk suchasnoi ukrainskoi movy [Large explanatory dictionary of the modern Ukrainian language]. Kyiv; Irpin: Perun [in Ukrainian].

3. Gerasimenko, S.L. (2007). Formirovaniye kommunikativnoy kultury budushchego meditsinskogo rabotnika $v$ protsesse izucheniya inostrannogo yazyka [Formation of a communicative culture of a future medical worker while learning a foreign language]. (Candidate's thesis). Kursk [in Russian].

4. Zagvyazinskiy, V.I., \& Atakhanov, R. (2005). Metodologiya i metody psikhologo-pedagogicheskogo issledovaniya [Methodology and methods of psychological and pedagogical research]. Moscow [in Russian].

5. Izmaylova, M.A. (2009). Delovoye obshcheniye [Business communication]. Moscow: Dashkov i K [in Russian].

6. Kodzhaspirova, G.M., \& Kodzhaspirov, A.Yu. (2005). Pedagogicheskiy slovar [Pedagogical Dictionary]. Moscow: Mart; Rostov-on-Don [in Russian].

7. Kononenko, B.I. (2003). Bolshoy tolkovyy slovar po kulturologii [The Large Explanatory Dictionary of Cultural Studies]. Moscow: Veche [in Russian].

8. Kruchek, V.A., \& Vasiuk, O.V. (2011). Kryterii ta pokaznyky sformovanosti kultury pedahohichnoi vzaiemodii [Criteria and indicators of the formation of the culture of pedagogical interaction]. Visnyk Cherkaskoho universytetu. Seriia «Pedahohichni nauky» - Bulletin of Cherkasy University. Series “Pedagogical Sciences”, 203(1), 99-104 [in Ukrainian].

9. Kuznetsova, V.H. (2001). Problemy formuvannia humanitarnoho svitohliadu studentskoi molodi [Problems of forming the humanitarian worldview of student youth]. Vis- nyk Luhanskoho derzhavnoho peduniversytetu imeni Tarasa Shevchenka - Bulletin of Taras Shevchenko Luhansk State Pedagogical University, 1, 96-101 [in Ukrainian].

10. Kurenkova, K.M. (2008). Pro tsinnisnyi zmist profesiinoi kultury maibutnikh fakhivtsiv [About the value content of the professional culture of future specialists]. Naukovi zapysky kafedry pedahohiky: zbirnyk naukovykh prats Scientific notes of the Department of Pedagogy: a collection of scientific works. Kharkiv [in Ukrainian].

11. Miasoid, H.I. (2005). Pedahohichni umovy rozvytku komunikatyvnoi kultury sotsialnykh inspektoriv u protsesi pidvyshchennia kvalifikatsii [Pedagogical conditions of development of communicative culture of social inspectors in skill improvement process]. (Candidate's Extended abstract). Ternopil [in Ukrainian].

12. Ostraus, Yu.M. (2016). Kryterii, pokaznyky ta rivni sformovanosti profesiino komunikatyvnoi kultury maibutnikh simeinykh likariv [Criteria, indicators and levels of formation of professional communication culture of future family doctors]. Naukovi zapysky Vinnytskoho derzhavnoho pedahohichnoho universytetu imeni Mykhaila Kotsiubynskoho. Seriia «Pedahohika i psykholohiia»-Scientific notes of Vinnytsia State Pedagogical University. Seria "Pedagogy and Psychology”, 47, 96-102 [in Ukrainian].

13. Petruk, H.M. (2008). Kryterii sformovanosti komunikatyvnoi kultury maibutnikh inzheneriv zviazku [Criteria of the formation of the communicative culture of future communications engineers]. Vytoky pedahohichnoi maisternosti: zbirnyk naukovykh prats. Seriia «Pedahohichni nauky» - The origins of teaching skills: a collection of scientific papers. Series "Pedagogical Sciences”. Poltava [in Ukrainian].

14. Vorona, I.I., \& Prokop, I. A. (2020). Professional culture in the context of future doctor training. Medychna osvita - Medical Education, 1, 117-121. 